\title{
Manganese exposure and the neuropsychological effect on children and adolescents: a review
}

\author{
José A. Menezes-Filho, ${ }^{1,2}$ Maryse Bouchard, ${ }^{3}$ \\ Paula de N. Sarcinelli, ${ }^{2}$ and Josino C. Moreira ${ }^{2}$
}

Suggested citation Menezes-Filho JA, Bouchard M, Sarcinelli PN, Moreira JC. Manganese exposure and the neuropsychological effect on children and adolescents: a review. Rev Panam Salud Publica. 2009;26(6):541-8.

ABSTRACT Objectives. Manganese $(\mathrm{Mn})$ is an essential element, but overexposure can have neurotoxic effects.

Methods. In this article, we review and summarize studies on exposure to $M n$ and nervous system impairments in children.

Results. We identified 12 original articles published between 1977 and 2007. Overexposure to $\mathrm{Mn}$ was suspected to occur through diverse sources: infant milk formula, drinking water, industrial pollution, and mining wastes. The most common bioindicator of exposure to $\mathrm{Mn}$ was hair Mn content, but some studies measured Mn in blood, urine, or dentin; one study on prenatal exposure measured Mn content in cord blood. Most studies indicate that higher postnatal exposure to $\mathrm{Mn}$ is associated with poorer cognitive functions and hyperactive behavior. Conclusions. The limitations of the existing studies are numerous: most were crosssectional, had a modest sample size, and lacked adjustment for important confounders. Future investigations should be performed on a larger sample size and include a more detailed exposure assessment, addressing multiple sources of exposure such as food, water, and airborne particulates.

Key words Manganese; neurobehavioral manifestations; cognition; neurotoxicity.

Manganese $(\mathrm{Mn})$ is very common in the environment, being the 5 th most abundant metal and the 12th most abundant element on earth (1). It is an essen-

\footnotetext{
1 Laboratory of Toxicology, Faculty of Pharmacy, Federal University of Bahia, Salvador, Bahia, Brazil. Send correspondence and reprint requests to: José A. Menezes-Filho, Faculdade de Farmácia, Federal University of Bahia, Av. Barão de Jeremoabo s/n Campus Universitário de Ondina, 41170-115 Salvador, Bahia, Brazil; telephone: 55-71-3283-6960; fax: 55-71-3283-6949; e-mail: antomen@ufba.br

2 Public and Environmental Health Program, National School of Public Health, Oswaldo Cruz Foundation, Av. Leopoldo Bulhões 1480 Manguinhos, Rio de Janeiro, Rio de Janeiro, Brazil.

3 Université du Québec à Montréal, CINBIOSE, Succursale Centre-ville, Montreal, Quebec H3C 3P8, Canada.
}

tial nutrient, with an adequate daily intake level of 1.8-2.6 milligrams (mg) for adults (2), but also has the potential to produce neurotoxic effects when, depending on the route and dose of exposure, it accumulates in an organism, especially in the brain (3). The vast majority of studies on neurotoxic effects of $\mathrm{Mn}$ were conducted in occupational settings where exposure occurs mainly though inhalation of airborne particulates. Few studies have investigated possible overexposure of children to Mn. It is generally accepted that children are at greater risk than adults exposed to the same contaminants from the environment (4). Although data are sparse, there is increas- ing concern for possible harmful effects of environmental exposures to $\mathrm{Mn}$, including the economic implications of intellectual deficits due to Mn toxicity (5).

$\mathrm{Mn}$ is an essential element, necessary for bone mineralization, energy and protein metabolism, regulation of cell metabolism, and protection against oxidative stress (6). With normal dietary consumption, systemic homeostasis of $\mathrm{Mn}$ is maintained by both its rate of transport across enterocytes lining the intestinal wall and its efficient removal in the liver (7). Ingested Mn is subjected to homeostatic mechanisms that regulate its concentration in the body, but exposure through inhalation bypasses most 
of these protective mechanisms. Therefore, inhaled Mn poses greater risks of toxicity, as seem to be supported by the preponderance of occupational reports of toxicity in environments with airborne exposure.

Mn shares several characteristics with iron $(\mathrm{Fe})$; both are transition metals with valences of $2^{+}$and $3^{+}$in physiological conditions and proximate ionic radius. In addition, as Mn and Fe both strongly bind to transferrin and accumulate in the mitochondria, low Fe stores are associated with increased Mn uptake and retention in the blood (8).

Neurotoxic effects resulting from excessive Mn exposure were first described by Couper in 1837 in Scottish laborers grinding Mn black oxide in the chemical industry (9). Neurological symptoms of manganism include decreased memory and concentration, fatigue, headache, vertigo, equilibrium loss, insomnia, tinnitus, trembling of fingers, muscle cramps, rigidity, alteration of libido, and sweating (10). Many reports of neurotoxic effects in Mn-exposed workers were later published (for a review, see Zoni et al. (11)), and the definition of Mn intoxication has evolved to include subclinical signs of intoxication indicated by alterations of neurobehavioral functions (12).

Mn can accumulate in the central nervous system, particularly the basal ganglia but also the cortex (13). Exposure to Mn was shown to interfere with several neurotransmitter systems, especially in the dopaminergic system in areas of the brain responsible for motor coordination, attention, and cognition (14, 15). $\mathrm{Mn}$ is a potent dopamine oxidant, which could explain the toxic lesions in certain dopaminergic brain regions (16). Excessive exposure could result in dopamine receptor loss or inactivation through damage to the membrane mediated by free radicals or cytotoxic quinones generated by the Mn catalyzing effect on autooxidation of this neurotransmitter (17). One hypothesis for the toxic mechanism of $\mathrm{Mn}$ is the production of excess free radicals in the nerve cell, potentiating lipid peroxidation and resulting in tissue destruction (18).

Several factors could predispose children to Mn overexposure and subsequent toxic effects. Exposure to Mn by ingestion or inhalation could have different consequences in children than in adults and through different mechanisms. First, the observed intestinal ab- sorption rate of ingested $\mathrm{Mn}$ in children was higher than in adults (19). Second, high demand for Fe linked to growth could further enhance the absorption of ingested Mn (20). Third, a low excretion rate was observed in infants due to the poorly developed biliary excretion mechanism in neonatal animals (21).

Data are lacking on the overall retention of ingested $\mathrm{Mn}$ in infants and children, but in mice, rats, and kittens, there is almost a complete absence of biliary Mn excretion during the neonatal period (22). With inhaled $\mathrm{Mn}$, the ratio of inhaled air/weight is much higher in children, leading to a higher dose of exposure for almost any contaminant in air. Thus, exposure during this period may result in increased delivery of $\mathrm{Mn}$ to the brain and other tissues.

Mn neurotoxicity has been extensively studied and a lot has been learned about its mechanism of action at the cellular and molecular levels and the detection of subclinical effects at low exposures, although there is a long way to go until its toxicology can be fully understood. Recently, several literature reviews have been published on aspects such as neurotoxic effects on exposed laborers (15, $23)$, the application of magnetic resonance imaging (24), neuropsychological testing for the assessment of Mn neurotoxicity (11), Mn neurotoxicity focused on neonates (25), and neurotoxicology of chronic Mn exposure in nonhuman primates (26).

As far as we know, no study has addressed the issue of children's exposure and the effect on behavior and cognition. Therefore, we propose here to review and summarize the scientific literature on the associations between Mn exposure and effects on children's neuropsychological functions.

\section{METHODOLOGY}

A systematic scientific literature search was carried out on the electronic database Medline (National Library of Medicine, Bethesda, Maryland, United States) for 1997-2007, using the keywords manganese, child, children, infant, childhood, adolescents, neurotoxicity, neuropsychological effects, behavior, motor, cognition, cognitive, intellectual functioning, hyperactivity, ADHD, and hyperactive behaviors. Upon reviewing a large number of article abstracts yielded by these search terms, we se- lected studies for this review only if information was presented that pertained specifically to assessment of the neuropsychological effects on children exposed to Mn from all possible sources. We found six articles on exposed populations in the United States, Canada, Spain, Bangladesh, and Malaysia. In the reference list of those articles, we selected six more investigation reports. Only full-length research articles were reviewed.

\section{RESULTS}

Table 1 shows a schematic summary of the studies with their general characteristics such as country of origin, type of design, sample size, source of exposure, and outcome investigated. In Table 2, we summarize the main findings of the studies. The first published article exploring a possible adverse neurobehavioral effect of exposure to Mn was a case-control study conducted in Canada on learningdisabled children (27). The authors postulated that nutritional deficiencies and exposure to toxic substances, using hair mineral content as an indicator of body burden, would be associated with learning disabilities in children. A cohort of third- and fourth-grade students was evaluated on a series of cognitive scales. The children diagnosed with a learning disability were compared with children without such a diagnosis and were matched by frequency for school attendance, grades, and gender; the groups had similar socioeconomic status. Children with learning disabilities had a significantly higher concentration of hair Mn as well as six other elements (sodium, cadmium, copper, lead, chromium, and lithium), which makes the findings difficult to interpret.

The high Mn concentration in infant milk formula drew the attention of researchers (28), who conducted a twopart study in the United States. First, hair Mn concentration was measured in children fed infant formula and in children exclusively breast-fed. Hair Mn levels were found to increase significantly from 0.19 microgram per gram $(\mu \mathrm{g} / \mathrm{g})$ at birth to $0.69 \mu \mathrm{g} / \mathrm{g}$ at 4 months in the infant formula group; no significant increase was observed in the breast-fed group. Second, the metal levels in the hair of children with hyperactivity were compared with those in age-matched children without this disorder. Signifi- 
TABLE 1. Characteristics of studies on the association between children's exposure to manganese and neuropsychological effects, published between 1977 and 2007

\begin{tabular}{|c|c|c|c|c|c|c|}
\hline Study & Country & Design & Subpopulation & $\begin{array}{c}N \\
\text { Exp./Ref. }{ }^{a}\end{array}$ & Exposure source & Effect sought \\
\hline Pihl and Parkes 1977 (27) & Canada & Case control & $\begin{array}{l}\text { Children in } 3 \text { rd and } 4 \text { th } \\
\text { grades ( } \pm 10 \text { years) }\end{array}$ & $31 / 22$ & Not reported & Learning deficit \\
\hline Collipp et al. 1983 (28) & $\begin{array}{l}\text { United } \\
\text { States }\end{array}$ & $\begin{array}{l}\text { Cross- } \\
\text { sectional }\end{array}$ & $\begin{array}{l}\text { Neonates and children } \\
\leq 10 \text { years }\end{array}$ & $16 / 44$ & Baby formula & $\begin{array}{l}\text { Hyperactivity } \\
\text { Learning deficit }\end{array}$ \\
\hline Barlow 1983 (29) & $\begin{array}{l}\text { United } \\
\text { Kingdom }\end{array}$ & $\begin{array}{l}\text { Cross- } \\
\text { sectional }\end{array}$ & $\begin{array}{l}\text { Children and adolescents } \\
\leq 16 \text { years }\end{array}$ & $68 / 65$ & Unknown & Hyperactivity \\
\hline He et al. $1994(30)$ & China & $\begin{array}{l}\text { Cross- } \\
\text { sectional }\end{array}$ & $\begin{array}{l}\text { Children 11-13 } \\
\text { years }\end{array}$ & $92 / 92$ & Drinking water & Neurobehavioral \\
\hline Zhang et al. 1995 (31) & China & $\begin{array}{l}\text { Cross- } \\
\text { sectional }\end{array}$ & Children $11-13$ years & $92 / 92$ & Drinking water & Learning deficit \\
\hline Woolf et al. 2002 (32) & $\begin{array}{l}\text { United } \\
\text { States }\end{array}$ & Case report & Child 10 years & 1 & Well water & $\begin{array}{l}\text { General } \\
\text { neuroeffects }\end{array}$ \\
\hline Takser et al. 2003 (33) & France & Prospective & Neonates & $\begin{array}{c}247 \\
(60 \% \text { loss })\end{array}$ & Mother's blood & $\begin{array}{l}\text { Psychomotor } \\
\text { development }\end{array}$ \\
\hline Torrente et al. 2005 (34) & Spain & $\begin{array}{l}\text { Cross- } \\
\text { sectional }\end{array}$ & Adolescents $12-14$ years & $54 / 45$ & Industrial pollution & Cognitive deficit \\
\hline Wasserman et al. 2006 (36) & Bangladesh & $\begin{array}{l}\text { Cross- } \\
\text { sectional }\end{array}$ & Children $10 \pm 0.5$ years & 142 & Well water & $\begin{array}{l}\text { Cognitive deficit } \\
\text { (intelligence quotient) }\end{array}$ \\
\hline Wright et al. 2006 (37) & $\begin{array}{l}\text { United } \\
\text { States }\end{array}$ & $\begin{array}{l}\text { Cross- } \\
\text { sectional }\end{array}$ & Adolescents $11-13$ years & 32 & Mining waste & $\begin{array}{l}\text { Neuropsychological } \\
\text { and neurobehavioral }\end{array}$ \\
\hline Ericson et al. 2007 (39) & $\begin{array}{l}\text { United } \\
\text { States }\end{array}$ & $\begin{array}{l}\text { Cross- } \\
\text { sectional in } \\
\text { a follow-up } \\
\text { cohort }\end{array}$ & Adolescents $11-13$ years & 27 & Mother's blood & $\begin{array}{l}\text { Behavioral } \\
\text { disinhibition }\end{array}$ \\
\hline Bouchard et al. 2007 (38) & Canada & $\begin{array}{l}\text { Cross- } \\
\text { sectional }\end{array}$ & $\begin{array}{l}\text { Children and adolescents } \\
6-15 \text { years }\end{array}$ & $28 / 18$ & Well water & $\begin{array}{l}\text { Hyperactive } \\
\text { behaviors }\end{array}$ \\
\hline
\end{tabular}

a Exp./Ref. = exposed/referents. $N=$ one studied group (no controls).

cantly higher levels of Mn were observed in the hair of hyperactive children $(0.43 \mu \mathrm{g} / \mathrm{g})$ than in controls $(0.27$ $\mu \mathrm{g} / \mathrm{g})$.

Barlow (29) investigated the association of Mn exposure and hyperactivity in the United Kingdom. A hair sample was collected by the family and sent to the researchers by mail. Slightly higher Mn concentrations were detected in children with hyperactivity $(0.84 \pm 0.64 \mu \mathrm{g} / \mathrm{g})$ than in controls $(0.68 \pm 0.45 \mu \mathrm{g} / \mathrm{g})$, although this difference was not significant $(p=0.10)$. The author identified several limitations-including the subjectivity of the diagnosis made by different psychiatrists, psychologists, and social workers-and the risk of contamination of hair samples. In addition, the control group was inappropriate, coming from a different area of residence, and socioeconomic status was not controlled.

A research group in China published two articles $(30,31)$ on the investigation of a rural community with Mn-contaminated drinking water following the use of high-Mn sewage water for irrigation.
The first publication addressed Mn levels in drinking water and children's hair and the associated neurobehavioral effects on children. The second article addressed the association of Mn hair and blood levels with learning deficiencies and the level of neurotransmitters measured in peripheral blood.

The exposed group was composed of 92 students from a village where the concentration of $\mathrm{Mn}$ in drinking water was between 0.24 and $0.35 \mathrm{mg}$ per liter (L) for many years. They were compared with children in another rural town with low $\mathrm{Mn}$ in water $(<0.03 \mathrm{mg} / \mathrm{L})$.

The children in both groups were evaluated by neurobehavioral tests that assessed emotional state, motor coordination, visual memory, and time of reaction. Children from the exposed village had a mean hair Mn concentration significantly higher than control children $(1.25 \pm 0.72 \mu \mathrm{g} / \mathrm{g}$ versus $0.96 \pm 0.42$ $\mu \mathrm{g} / \mathrm{g}$ ); the same difference was observed with Mn blood levels $(33.9 \mu \mathrm{g} / \mathrm{L}$ versus $22.6 \mu \mathrm{g} / \mathrm{L})$. Children from the exposed village had lower performance $(p<0.01)$ than controls on 5 of 12 neurobehavioral tests: digit span, Santa Ana manual dexterity, digit symbol, Benton visual retention test, and pursuit aiming test. In addition, exposed children had significantly lower school performance than the control children. Multiple regression analysis showed that school grade for language and mathematics was correlated to serum levels of the neurotransmitters 5-hydroxytryptamine, norepinephrine, and dopamine and to the activity of acetylcholinesterase.

Woolf and associates (32) reported a case of suspected $\mathrm{Mn}$ intoxication in a 10-year-old child from a suburb of Boston, Massachusetts (United States). For more than 5 years, the family had used water from a tube well with a very high Mn concentration (1.21 mg/L). The child had high Mn levels in serum (9.00 $\mu \mathrm{g} / \mathrm{L}$, reference normal $<0.27 \mu \mathrm{g} / \mathrm{L}$ ), whole blood $(38.2 \mu \mathrm{g} / \mathrm{L}$, reference normal < $14.0 \mu \mathrm{g} / \mathrm{L})$, and hair $(3.09 \mu \mathrm{g} / \mathrm{g}$, reference normal $<1.20 \mu \mathrm{g} / \mathrm{g}$ ). However, magnetic resonance imaging showed no changes in the globus pallidus and basal 
TABLE 2. Results of studies on the association between children's exposure to manganese and neuropsychological effects, published between 1977 and 2007

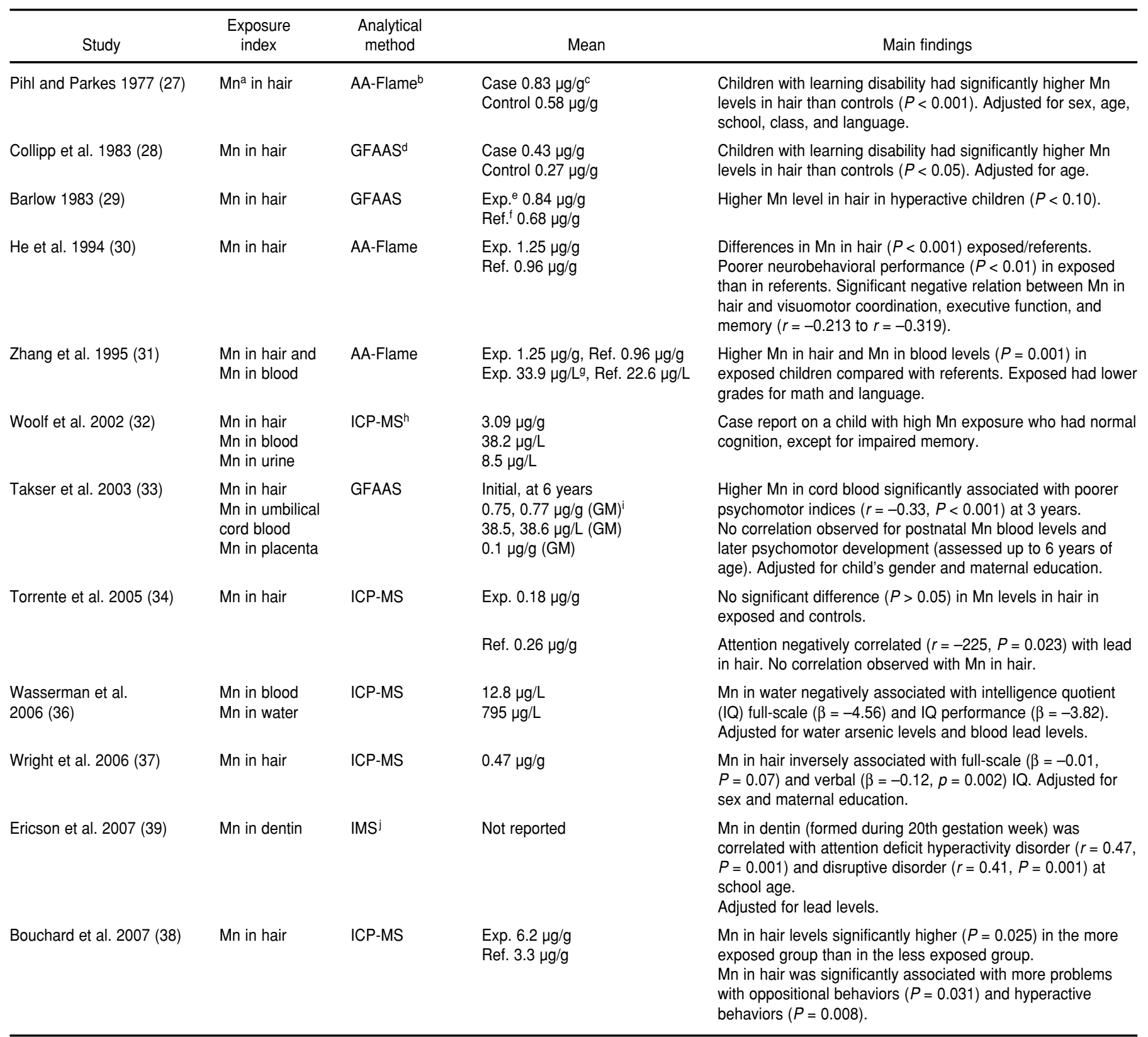

${ }^{\mathrm{a}} \mathrm{Mn}=$ manganese.

${ }^{\mathrm{b}} \mathrm{AA}$-Flame = atomic absorption spectroscopy, flame mode.

${ }^{c} \mu \mathrm{g} / \mathrm{g}=$ micrograms per gram.

${ }^{d}$ GFAAS = graphite furnace atomic absorption spectrometry.

exp. $=$ exposed.

${ }^{\dagger}$ Ref. $=$ referents

${ }^{g} \mu \mathrm{g} / \mathrm{L}=$ micrograms per liter

hICP-MS = inductively coupled plasma mass spectrometry.

${ }^{i} \mathrm{GM}=$ geometric mean.

j IMS = ion mass spectrometry.

ganglia that indicated $\mathrm{Mn}$ accumulation. The results of a battery of neuropsychological tests (Table 2) showed that the child had a normal intelligence quotient (IQ) but unexpectedly poor verbal and visual memory as well as the ability to coordinate alternating movements. The child had no medical history that explained these findings. The detailed neurological evaluation was otherwise normal, with no tremors, normal gait and muscle tone, and no cog wheeling, nys- tagmus, or fixed faces. The patient's balance was good, fine motor skills and reflexes were normal, and the sensory examination was unremarkable. The mother reported that teachers had noticed the inattentiveness of the child. The 
family discontinued all use of well water and the residence was connected to the municipal water system. Eighteen months later, teachers continued to observe his difficulty in carrying out certain tasks due to attention deficit. It is noteworthy that the 16-year-old brother of this child had normal psychometric evaluation, with elevated Mn in hair but not in blood.

Takser and associates (33) conducted a prospective epidemiologic study in 247 healthy pregnant women and their babies to investigate the long-term effect of in utero Mn levels on their children's psychomotor development. The population was recruited from a maternity hospital in Paris (France). Mn levels were measured in the mothers' blood and hair at delivery, in umbilical cord blood, and in placental tissue; children's hair and monoamine (dopamine and serotonin) metabolite concentrations were assessed in umbilical cord plasma. Children's development was assessed at 9 months with the Brunet-Lézine scales, and at 3 and 6 years of age with the McCarthy scales. The results showed significant negative correlations between Mn levels in cord blood and nonverbal scales (attention, nonverbal memory) and boys' manual ability at 3 years, after adjusting for potential confounders (sex and mother's educational level). However, no relation between $\mathrm{Mn}$ and development subscales was observed at the 6-year follow-up. The authors concluded that the exposure to high in utero Mn levels can affect children's psychomotor development but that sociocultural factors might have masked Mn effects in older children. Finally, it was emphasized that fetal life can be regarded as a period of great vulnerability to Mn toxicity at low environmental levels.

A cross-sectional study was performed in Spain (34) with the objective of investigating correlations between hair metal concentrations and cognitive functions of adolescents living in areas with contrasting levels of industrial contamination. One hundred adolescents (12-14 years old) were selected from schools in urban areas and in the vicinity of the industrial complex in the region of Tarragona, Catalonia. Hair samples were collected for analysis of cadmium, chromium, mercury, lead, Mn, nickel, and tin by inductively coupled plasma mass spectroscopy. The attention span test was used as an indicator of attention, and tests of visuospatial abilities and abstract reasoning were used as a general intelligence index. No significant correlations were found between chromium, Mn, nickel, and tin levels and cognitive measures. A negative correlation was found between hair lead level and the ability to concentrate, after adjustment for socioeconomic status, and a positive correlation was observed between mercury and visuospatial ability. The authors suggested that the mercury might come from consumption of fish, also associated with a high intake of fatty acids with a beneficial effect on brain function.

Wasserman and associates (35) investigated the association between Mn exposure from well water and children's IQ in Bangladesh. In a previous study, Mn levels were found to be associated with arsenic levels, and intellectual function was negatively related to both metals. However, the association between $\mathrm{Mn}$ and intellectual function was no longer significant when the level of arsenic in water was included in the regression model. Therefore, a study (36) was designed to test the hypothesis that Mn had an independent effect on cognitive function. In the new study, 54 children were added who lived in houses supplied by water with very low arsenic levels $(<10 \mu \mathrm{g} / \mathrm{L})$. All children received a complete clinical examination and provided urine samples for determination of arsenic and a blood sample for $\mathrm{Mn}$, lead, and arsenic determination. Intellectual function was evaluated by the Wechsler Intelligence Scale for Children version III (WISC-III), providing three IQ scores: verbal, performance, and full scale. After adjusting for covariables (mother's schooling, quality of housing, access to television, and cranial circumference), increasing $\mathrm{Mn}$ water levels were associated with lower IQ on all three scales. Mn levels in water were not associated with $\mathrm{Mn}$ in whole blood, and the latter were not associated with WISC-III scores.

In the study conducted by Wright and collaborators (37), the interaction of children with coexposure to $\mathrm{Mn}$ and arsenic was also evaluated. Hair was used as a biomarker, psychometric scales were used to assess cognitive functioning, and a series of other scales were administered for behavioral evaluation (see Table 2). The main finding of this study was that high levels of both Mn and arsenic were significantly associated with lower intellectual function and verbal memory scores.

Bouchard and collaborators (38) evaluated children from a community in Quebec, Canada, which was served by municipal water supplied from two wells with different $\mathrm{Mn}$ concentrations $(0.61 \mathrm{mg} / \mathrm{L}$ versus $0.16 \mathrm{mg} / \mathrm{L})$. Forty-six children participated in the study (median age 11 years, range $6-15$ years). Mn levels were measured in children's hair, and parents and teachers completed the Conner's Rating Scale on hyperactive/ attention deficit behaviors. The results showed that (1) children living in houses supplied with water at higher Mn concentrations had significantly higher levels of Mn in hair, and (2) hair Mn concentrations were associated with higher scores for hyperactive and oppositional behavior in the classroom after adjusting for age, gender, and family income. In addition, all children with high scores on these subscales, based on clinical cut-off provided by the test manual, had hair Mn levels higher than the upper limit of the reference range $(>3.0 \mu \mathrm{g} / \mathrm{g})$. An intriguing result of this study is that $90 \%$ of the children did not drink water from the tap, but elevated Mn levels were found in hair of a large proportion of them; use of tap water in food preparation or in showering might contribute to the dose of exposure. This pilot study was used to design a larger epidemiologic study on the effects of exposure to $\mathrm{Mn}$ in tap water and food.

In another study in the same year, Ericson and associates (39) evaluated neurobehavioral effects with scales that measure the degree of disinhibition. Unlike previous investigations, the enamel of shedding teeth was used as a matrix for Mn determination, with the objective of measuring the previous exposure during the intrauterine stage when these tissues were formed. The children of this study were randomly selected from a cohort of normal newborns from a prospective developmental study started in 1991 in the United States. Three psychometric tests had been directly applied to children in two phases of development: at 36 and 54 months. Scales that assessed behavior were applied to parents and teachers when children were in the first and third grades. The authors concluded that, even after adjusting for levels of lead in the tooth enamel, measured at the same time as $\mathrm{Mn}$, children with high levels of this metal in the uterine 
phase had higher scores on all scales of disinhibitory behavior: more children played with forbidden toys at 36 months of age, committed more errors by impulsiveness at 54 months, and were more often evaluated by their mothers and teachers as having externalizing and attention problems.

\section{DISCUSSION}

The literature on possible adverse effects of exposure to Mn on children's health is relatively sparse, despite the fact that $\mathrm{Mn}$ is acknowledged to be a neurotoxin. There are some indications in the literature that Mn exposure might be related to cognitive deficits and hyperactive behaviors.

Five studies reported indications of adverse effects of exposure to $\mathrm{Mn}$ in water on the central nervous system of children $(29,31,32,36,38)$. Given that high levels of $\mathrm{Mn}$ in well water are not uncommon, this situation could pose a significant public health risk. Mn levels corresponding to the level found in the Chinese study to have a significant effect on children (around $0.3 \mathrm{mg} / \mathrm{L}$ ) are found in $6 \%$ of household wells in the United States (40).

Two studies $(33,39)$ addressed possible adverse neurobehavioral effects from in utero exposure to $\mathrm{Mn}$, although sources of exposure were not specified. It is well documented that Mn levels rise in the mother's blood, where Mn has an important role as a cofactor of several enzymes that regulate metabolism and bone growth $(40,41)$. Although newborns' exposure to Mn through infant milk formula is a cause for concern (see the review by Ericson et al. (39)), only one investigation addressed this possible source of exposure (29), despite the fact that baby formulas, especially those based on soybean, have been shown to have considerably high Mn levels (42, 43).

Children's exposure to Mn resulting from environmental contamination was addressed in Spain (34), and no significant association was found between $\mathrm{Mn}$ levels and cognitive deficits, and in the United States (37), where significant associations with cognitive deficits have been observed in children living near a mining waste site.

Another study (29) evaluated children from the general population with no known exposure and reported associa- tions based on the level of Mn in different biological tissues. The lack of detailed exposure assessment to identify Mn sources precludes the proper determination of the risk factors and therefore does not allow for proposing solutions to reduce exposure.

Studies published so far have several serious limitations, including sample size, research design, adjustment for potential confounding variables, and control of coexposure to other neurotoxicants. All reviewed studies except that of Takser and colleagues (33) were crosssectional and had a modest sample size. Cross-sectional studies provide less convincing evidence than cohort studies in showing a potentially harmful effect. Most studies attempted to control for confounders by design, selecting a reference group matched on some important variables (i.e., socioeconomic status, age, gender) or controlling confounders by restriction, as in the study of Wasserman et al. (35), which selected households supplied with water containing low levels of arsenic.

The early studies had greater limitations in this respect. For instance, in the study by Pihl and Parkes (27), the only controlled variable was age. The significant difference observed in the levels of $\mathrm{Mn}$ in hair in children with and without a learning disability could have been associated with metal exposure from other sources-for example, due to airborne particulate matter exposure from vehicular traffic and soil or dust around residences or different levels of exposure to metals from the diet. Although it is known that maternal educational level has a large influence on children's intellectual development, only three of the reviewed studies controlled for this factor $(33,36,37)$.

Studies conducted in the occupational setting reported relationships between neurological outcomes and concentration of airborne Mn. However, the levels of exposure in the general environment are several orders of magnitude lower than in most occupational settings where $\mathrm{Mn}$ is present in the process and therefore are more difficult to measure. For example, a concentration of $80.2 \mu \mathrm{g}$ of Mn per cubic meter $\left(\mathrm{m}^{3}\right)$ was reported in the air of a ferromanganese plant (44), a Mn range of $1.5-450 \mathrm{mg} / \mathrm{m}^{3}$ was reported in mines in the United States (45), but the level in the air in nonindustrialized regions is expected to be at most
$0.15 \mu \mathrm{g} / \mathrm{m}^{3}$ (46). In general, studies that measure exposure from environmental sources will always have weaker exposure levels and consequently the possibility of an association will be overshadowed by confounding variables.

One difficulty in the study of Mn exposure is the lack of a well-recognized bioindicator of exposure. Most studies reviewed here used hair as an indicator of $\mathrm{Mn}$ exposure, except for the Wasserman et al. study (36), which measured $\mathrm{Mn}$ in blood, and the Ericson et al. study (39), which used Mn in the dentin of deciduous teeth as a biomarker of in utero exposure. Use of hair has several advantages over other biomarkers. Hair averages off the variations of $\mathrm{Mn}$ levels found in blood or plasma, as it grows an average of 11 millimeters/month, thus representing a time-weighted average over the duration of exposure. In addition, the sample collection procedure is simple, can be performed by minimally trained staff, and is not invasive. A major drawback to the use of hair as a marker of internal dose of exposure is exogenous deposition, which is particularly problematic in the context of exposure to airborne Mn particulates. Washing can minimize the problem of external contamination, but using a very abrasive reagent can erode the capillary structure, leading to loss of endogenous elements. Research would benefit from a standardized washing procedure.

Others have hypothesized the possibility of overexposure to Mn through ingestion of infant milk formula (47), showering in water with a high $\mathrm{Mn}$ level (48), and adding methylcyclopentadienyl manganese tricarbonyl (MMT) to gasoline (49). Whether these exposures represent a significant toxic risk remains to be investigated, but some exposure data suggest that might be the case. In a study in South Africa, levels of Mn in deposited dust and in blood of children were compared in Johannesburg, where the gasoline additive MMT had been used for 1 year, and in Cape Town, where MMT is not used. The mean level of $\mathrm{Mn}$ in dust and blood was significantly higher in Johannesburg than in Cape Town (blood Mn $9.8 \pm 3.6 \mu \mathrm{g} / \mathrm{L}$ versus $6.7 \pm 3.5 \mu \mathrm{g} / \mathrm{L}$ ). In addition, a significant association was found between Mn in classroom dust and children's Mn blood levels (50).

Although limited by poor study design and difficulties in exposure assess- 
ment, the evidence of adverse effects from $\mathrm{Mn}$ environmental exposure on children is compelling enough to warrant further research. Future investigations based on a prospective design will shed more light on the relation of Mn exposure and neuropsychological effects on environmentally exposed children. Finally, it is of paramount importance that epidemiologic studies include a tute of Occupational Medicine. Occupational exposure limits: criteria document for manganese and inorganic manganese compounds. Web report W17. Leicester, United Kingdom: Medical Research Council, Institute for Environment and Health; 2004. Available from: http://www.le.ac.uk/ieh. Accessed 25 March 2008.

2. Institute of Medicine. Dietary reference intakes for vitamin A, vitamin $\mathrm{K}$, arsenic, boron, chromium, copper, iodine, iron, manganese, molybdenum, nickel, silicon, vanadium, and zinc (2000). Washington, DC: IOM; 2001.

3. World Health Organization. Manganese. Environmental health criteria 17. Geneva: WHO; 1981.

4. World Health Organization. Principles for evaluating health risks in children associated with exposure to chemicals. Environmental health criteria 237. Geneva: WHO; 2006.

5. Weiss, B. Economic implications of manganese neurotoxicity. Neurotoxicology. 2006;27: 362-8.

6. Keen CL, Ensunsa JL, Clegg, MS. Manganese metabolism in animals and humans including the toxicity of manganese. Met Ions Biol Syst. 2000;37:89-121.

7. Papavasiliou PS, Miller ST, Cotzias GC. Role of liver in regulating distribution and excretion of manganese. Am J Physiol. 1966;211(1): 211-6.

8. Roth JA. Homeostatic and toxic mechanisms regulating manganese uptake, retention, and elimination. Biol Res. 2006;39(1):45-57.

9. Iregren A. Manganese neurotoxicity in industrial exposures: proof of effects, critical exposure level, and sensitive tests. Neurotoxicology. 1999;20:315-24.

10. Tanaka S. Manganese and its compounds. In: Zenz C, ed. Occupational medicine: principles and practical applications. Chicago: Year Book Medical Publishers; 1988. Pp. 583-9.

11. Zoni S, Albini E, Lucchini R. Neuropsychological testing for the assessment of manganese neurotoxicity: a review and a proposal. Am J Ind Med. 2007;50(11):812-30.

12. Mergler D. Neurotoxic effects of low level exposure to manganese in human populations. Environ Res. 1999;80:99-102.

13. Guilarte TR, McGlothan JL, Degaonkar M, Chen M, Barker PB, Syversen T, et al. Evi- comprehensive environmental assessment in order not only to better understand the exposure pathways but also to provide reliable data for risk assessment, which can be used later to design efficient interventions to abate exposure.

Acknowledgments. This review is part of the doctoral thesis project of José

\section{REFERENCES}

dence for cortical dysfunction and widespread manganese accumulation in the nonhuman primate brain following chronic manganese exposure: a 1H-MRS and MRI study. Toxicol Sci. 2006;94(2):351-8.

14. Dobson AW, Erikson KM, Aschner M. Manganese neurotoxicity. Ann N Y Acad Sci. 2004;1012:115-28.

15. Mergler D, Baldwin M. Early manifestations of manganese neurotoxicity in humans: an update. Environ Res. 1997;73:92-100.

16. Pal PK, Samii A, Calne DB. Manganese neurotoxicity: a review of clinical features, imaging and pathology. Neurotoxicology. 1999;20 (2-3):227-38

17. Fitsanakis VA, Au C, Erikson KM, Aschner $\mathrm{M}$. The effects of manganese on glutamate, dopamine and gamma-aminobutyric acid regulation. Neurochem Int. 2006;48:426-33.

18. Graham DG. Catecholamine toxicity: a proposal for the molecular pathogenesis of manganese neurotoxicity and Parkinson's disease. Neurotoxicology. 1984;5:83-96.

19. Dorner K, Dziadzka S, Hohn A, Sievers E, Oldigs HD, Schulz-Lell G, et al. Longitudinal manganese and copper balances in young infants and preterm infants fed on breast-milk and adapted cow's milk formulas. Br J Nutr. 1989;61:559-72.

20. Mena I, Horiuchi K, Burke K, Cotzias GC. Chronic manganese poisoning: individual susceptibility and absorption of iron. Neurology. 1969;19:1000-6.

21. Cotzias GC, Miller ST, Papavasiliou PS, Tang LC. Interactions between manganese and brain dopamine. Med Clin North Am. 1976; 60:729-38.

22. Cotzias GC, Horiuchi K, Fuenzalida S, Mena I. Chronic manganese poisoning: clearance of tissue manganese concentrations with persistence of the neurological picture. Neurology. 1968;18:376-82.

23. Antonini JM, Santamaria AB, Jenkins NT, Albini E, Lucchini A. Fate of manganese associated with the inhalation of welding fumes: potential neurological effects. Neurotoxicology. 2006;27:304-10.

24. Fitsanakis V, Zhang N, Avison MJ, Gore JC, Aschner JL, Aschner M. The use of magnetic resonance imaging (MRI) in the study of manganese neurotoxicity. Neurotoxicology. 2006;27(5):798-806.

25. Erikson KM, Thompson K, Aschner J, Aschner $M$. Manganese neurotoxicity: a focus on
A. Menezes-Filho, who has a scholarship from CAPES (Brazilian governmental agency). The project “Children's exposure to manganese from a ferro-manganese plant" was partially financed by the Fogarty International Center, National Institutes of Health Grant 1 D43 TW000640. He is also a scholar of the Irving Selikoff International Foundation, Mount Sinai School of Medicine. the neonate. Pharmacol Ther. 2007;113(2): 369-77.

26. Burton NC, Guilarte TR. Manganese neurotoxicity: lessons learned from longitudinal studies in nonhuman primates. Environ Health Perspect. 2009;117(3):325-32.

27. Pihl RO, Parkes M. Hair element content in learning disabled children. Science. 1977;198: 204-6.

28. Collipp PJ, Chen SY, Maitinsky CS. Manganese in infant formulas and learning disability. Ann Nutr Metab. 1983;27:488-94.

29. Barlow PJ. A pilot study on the metal levels in the hair of hyperactive children. Med Hypotheses. 1983;11:309-18.

30. He P, Liu DH, Zhang GQ. Effects of highlevel-manganese sewage irrigation on children's neurobehavior. Zhonghua Yu Fang Yi Xue Za Zhi. 1994;28(4):216-8.

31. Zhang G, Liu D, He P. A preliminary study of the effects of manganese on learning abilities of primary school pupils. Zhonghua Yu Fang Yi Xue Za Zhi. 1995;29(3)157:156-8.

32. Woolf A, Wright R, Amarasiriwardena C, Bellinger D. A child with chronic manganese exposure from drinking water. Environ Health Perspect. 2002;110(6):613-6.

33. Takser L, Mergler D, Hellier G, Sahuquillo J, Huel G. Manganese, monoamine metabolite levels at birth, and child psychomotor development. Neurotoxicology. 2003;24: $667-74$.

34. Torrente M, Colomina MT, Domingo JL. Metal concentrations in hair and cognitive assessment in an adolescent population. Biol Trace Elem Res. 2005;104:215-21.

35. Wasserman GA, Liu X, Parvez F, Ahsan $H$, Factor-Litvak P, van Geen A, et al. Water arsenic exposure and children's intellectual function in Araihazar, Bangladesh. Environ Health Perspect. 2004;12:1329-33.

36. Wasserman GA, Liu X, Parvez F, Ahsan H, Levy D, Factor-Litvak $\mathrm{P}$, et al. Water manganese exposure and children's intellectual function in Araihazar, Bangladesh. Environ Health Perspect. 2006;114(1)124-9.

37. Wright $\mathrm{RO}$, Amarasiriwardena $\mathrm{C}$, Woolf $\mathrm{AD}$, Jim R, Bellinger DC. Neuropsychological correlates of hair arsenic, manganese, and cadmium levels in school-age children residing near a hazardous waste site. Neurotoxicology. 2006;27:210-6.

38. Bouchard M, Laforest F, Vandelac L, Bellinger D, Mergler D. Hair manganese and hy- 
peractive behaviors: pilot study of school-age children exposed through tap water. Environ Health Perspect. 2007;15(1):122-7.

39. Ericson JE, Crinella FM, Clarke-Stewart KA, Allhusen VD, Chan T, Robertson RT. Prenatal manganese levels linked to childhood behavioral disinhibition. Neurotoxicol Teratol. 2007;29:181-7.

40. U.S. Geological Survey. National waterquality assessment program. Reston, VA: USGS; 2005. Available from: http://water. usgs. gov/nawqa/. Accessed 1 October 2005.

41. Krachler M, Rossipal E, Micetic-Turk D. Trace element transfer from the mother to the newborn-investigations on triplets of colostrums, maternal and umbilical cord sera. Eur J Clin Nutr. 1999;53:486-94.

42. Lonnerdal B, Keen CL, Ohtake M, Tamura T. Iron, zinc, copper and manganese in infant formulae. Am J Dis Child. 1983;137: 433-7.
43. Golub MS, Hogrefe CE, Germann SL, Tran TL, Beard JL, Crinella FM, et al. Neurobehavioral evaluation of rhesus monkey infants fed cow's milk formula, soy formula, or soy formula with added manganese. Neurotoxicol Teratol. 2005;27:615-27.

44. VEEP (Veredas Estudos e Execução de Projetos Ltda). Technical Report: "Relatório Final do Estudo Epidemiológico para Verificação de Efeitos sobre a Saúde da População Circunvizinha à Empresa RDM". Simões Filho: Novembro 2005.

45. Agency for Toxic Substances and Disease Registry. Toxicological profile for manganese. Washington, DC: U.S. Department of Health and Human Services, Public Health Service; 2000. Available from: http://www.atsdr. cdc.gov/toxprofiles/tp151.html. Accessed September 2000.

46. World Health Organization. Manganese. International programme on chemical safety.
Environmental health criteria 17. Geneva: WHO; 1981.

47. Aschner, M. Manganese: brain transport and emerging research needs. Environ Health Perspect. 2000;108(3):429-32.

48. Elsner RJ, Spangler JG. Neurotoxicity of inhaled manganese: public health danger in the shower? Med Hypotheses. 2005;65:607-16.

49. Lynam DR, Roos JW, Pfeifer GD, Fort BF Pullin TG. Environmental effects and exposures to manganese from use of methylcyclopentadienyl manganese tricarbonyl (MMT) in gasoline. Neurotoxicology. 1999;20:145-50.

50. Rollin H, Mathe A, Levin J, Theodorou P, Wewers F. Blood manganese concentrations among first-grade schoolchildren in two South African cities. Environ Res. 2005;97: 93-9.

Manuscript received on 18 March 2009. Revised version accepted for publication on 28 July 2009.

RESUMEN Objetivo. El manganeso $(\mathrm{Mn})$ es un elemento esencial, pero la sobreexposición puede tener efectos neurotóxicos.

Métodos. En este artículo se hace una revisión y un compendio de los estudios pu-

Exposición al manganeso y su efecto neurosicológico en niños y adolescentes: una revisión

Palabras clave blicados sobre la exposición al Mn y los trastornos del sistema nervioso en niños.

Resultados. Se identificaron 12 artículos originales publicados entre 1977 y 2007. La sobreexposición al Mn puede haber ocurrido a partir de diversas fuentes: leche en polvo o maternizada, agua de beber, polución industrial y desechos de la producción minera. El bioindicador de exposición utilizado con mayor frecuencia fue el contenido de Mn en el pelo, aunque algunos estudios lo midieron en la sangre, la orina o la dentina; un estudio sobre exposición prenatal midió su contenido en la sangre del cordón umbilical. La mayoría de los estudios indican que una mayor exposición posnatal al Mn se asocia con deficiencias en las funciones cognitivas y el comportamiento hiperactivo.

Conclusiones. Las limitaciones de los estudios publicados son numerosas: la mayoría de ellos eran transversales, se basaban en muestras pequeñas y en ellos no se ajustaron los resultados por importantes factores de confusión. Se requieren investigaciones adicionales con muestras mayores y que hagan una evaluación más detallada de la exposición, tomando en cuenta múltiples fuentes, como los alimentos, el agua y las partículas suspendidas en el aire.

Manganeso; manifestaciones neurocomportamentales; cognición; intoxicación por manganeso. 